\title{
Mind the Gap
}

\section{A systematic review to identify usability and safety challenges and practices during electronic health record implementation}

Raj Ratwani'; Terry Fairbanks'; Erica Savage'; Katie Adams'; Michael Wittie²; Edna Boone; Andrew Hayden; Janey Barnes ${ }^{3}$; Zach Hettinger ${ }^{1}$; Andrew Gettinger ${ }^{2}$

${ }^{1}$ National Center for Human Factors in Healthcare, MedStar Health, Washington D.C.;

${ }^{2}$ Office of the National Coordinator of Health Information Technology, Washington D.C.;

${ }^{3}$ User-View, Raleigh, North Carolina

\section{Keywords}

Usability, safety, human factors, electronic health records, implementation

\section{Summary}

Objective: Decisions made during electronic health record (EHR) implementations profoundly affect usability and safety. This study aims to identify gaps between the current literature and key stakeholders' perceptions of usability and safety practices and the challenges encountered during the implementation of EHRs.

Materials and Methods: Two approaches were used: a literature review and interviews with key stakeholders. We performed a systematic review of the literature to identify usability and safety challenges and best practices during implementation. A total of 55 articles were reviewed through searches of PubMed, Web of Science and Scopus. We used a qualitative approach to identify key stakeholders' perceptions; semi-structured interviews were conducted with a diverse set of health IT stakeholders to understand their current practices and challenges related to usability during implementation. We used a grounded theory approach: data were coded, sorted, and emerging themes were identified. Conclusions from both sources of data were compared to identify areas of misalignment.

Results: We identified six emerging themes from the literature and stakeholder interviews: cost and resources, risk assessment, governance and consensus building, customization, clinical workflow and usability testing, and training. Across these themes, there were misalignments between the literature and stakeholder perspectives, indicating major gaps.

Discussion: Major gaps identified from each of six emerging themes are discussed as critical areas for future research, opportunities for new stakeholder initiatives, and opportunities to better disseminate resources to improve the implementation of EHRs.

Conclusion: Our analysis identified practices and challenges across six different emerging themes, illustrated important gaps, and results suggest critical areas for future research and dissemination to improve EHR implementation.

\section{Correspondence to:}

Raj Ratwani, PhD

National Center for Human Factors in Healthcare,

MedStar Health,

Washington D.C.

Email: raj.ratwani@medicalhfe.org

\section{Appl Clin Inform 2016; 7: 1069-1087}

http://dx.doi.org/10.4338/ACI-2016-06-R-0105

received: June 28,2016

accepted: September 27, 2016

published: November 16, 2016

Citation: Ratwani $R$ et al.: Review to identify usability and safety challenges and practices during EHR implementation. Appl Clin Inform 2016; 7: 1069-1087

http://dx.doi.org/10.4338/ACl-2016-06-R-0105 


\section{Background and Significance}

There is no dispute that electronic health records (EHRs) have the potential to improve the efficiency, safety, and quality of healthcare $[1,2]$. However, to fulfill this potential, EHRs must be properly designed, developed, implemented, and used. Usability has emerged as a major factor limiting EHRs' realization of their full potential [3-5]. Suboptimal usability leads to inefficiencies, clinician frustration and stress - and poses serious hazards that have resulted in patient harm [6,7].

Usability is formally defined as the effectiveness, efficiency, and satisfaction with which specified users achieve specified goals in a particular environment [8]. There is a common misconception that usability focuses solely on screen design elements such as color, font, and iconography. While good interface design is important, usability in the context of health IT extends beyond that and entails developing an in-depth understanding of how frontline health care professionals ("end users") perform their work, so that systems can be developed to support the user's cognitive needs [9-11.

Several aspects of the EHR product lifecycle can affect the EHRs' usability as experienced by end users. EHR system design and development is a major focus of the Office of the National Coordinator's certification program and a major focus area for researchers seeking to develop and provide tools for EHR developers to improve their systems' usability [12-15].

Implementation has received considerably less attention from policymakers and researchers. However, implementation is recognized as a time of tremendous risk, and decisions made after purchase during implementation have a direct impact on usability and safety [16]. During implementation, the product is configured and may be customized to meet particular needs based on workflow, preferences, and interoperability with other health information technology systems. End users must also learn how to use the system, and generally receive some form of training during implementation.

The American Medical Informatics Association's recommendations to improve EHR usability and safety highlight the need for both health IT developers and implementers to adopt best practices [17]. However, what these best practices are, and whether there are gaps between the challenges faced during implementation and best practices available to address these challenges, remains unclear. While most healthcare institutions have already adopted EHRs, one report suggests twenty percent of hospitals are considering switching to a different EHR product in the near future, and many small to midsize healthcare institutions are also considering different products $[18,19]$. The quality of future implementations could be enhanced by identifying areas that need focused improvements.

\section{Objective}

The purpose of this review is to identify usability and safety challenges and best practices during EHR implementation, with a focus on gaps between the literature and key stakeholders. Our objectives were to (1) identify usability and safety practices and challenges during implementation as described in the published literature, (2) determine key stakeholder perceptions of current practices and challenges, and (3) compare these data to identify knowledge gaps and opportunities related to EHR implementation processes.

\section{Materials and Methods}

We conducted a systematic review of the literature and interviews with key health IT stakeholders. Each method is described separately.

\section{Literature Review Methodology}

The literature describing challenges and practices during EHR implementation is generally not based on empirical research trials describing effects, but rather on perspectives, case studies, and general assessments. Thus, we followed well-established systematic review methods used in reviews 
with a similar purpose [20]. We adapted the Preferred Reporting Items for Systematic Reviews and Meta-analyses checklist to remove items that are focused on empirical studies with effects [21].

\section{Search process}

We searched PubMED, Scopus, and Web of Science in April 2016 using a combination of search terms to capture articles about safety and usability during EHR implementation. We included peerreviewed articles in English that had been published from 2010 to May 16, 2016. We did not search earlier than 2010 because most EHRs were implemented on or after this year. $>$ Table 1 shows details of the search queries.

\section{Selection process}

For inclusion, articles must address EHR usability and safety as affected by implementation and describe practices, lessons learned, or challenges associated with implementation. Articles that focused on the development and implementation of specific algorithms or alerts, and articles measuring differences in clinician performance pre- and post- implementation were excluded unless the generalizable practices, lessons learned, or challenges were detailed.

Article selection started with three reviewers (KA, ES, RR) manually reviewing the titles and abstracts of all of the unique retrieved articles from the search query and excluding those not meeting our criteria. The full text of the remaining 86 articles was retrieved and three reviewers (KA, ES, RR) reviewed each article for inclusion in the final analysis. If it was unclear as to whether the article should be included it was discussed by the larger group of authors for a decision. Fifty-five articles were identified as meeting our criteria of highlighting a best practice or challenge during the implementation phase.

\section{Data extraction and synthesis}

Three members of the research team (KA, ES, RR) reviewed each article and extracted the challenges and practices. Many articles described multiple challenges or practices, so each of these was captured separately. We used a grounded theory approach to identify emerging themes and the practices and challenges within those themes [22]. Any disagreements amongst the three members were discussed with the larger group of authors to reach a resolution.

\section{Stakeholder Interview Methodology}

We conducted interviews with health IT stakeholders to identify current perceptions of the practices and challenges related to usability and safety during implementation.

\section{Recruitment}

Based on the authors' previous work, we identified five key stakeholder categories, and recruited eight to nine participants from each category using a purposive sampling method to recruit individuals with extensive knowledge of the perspective they would represent ( Table 2) $[12,23]$.

\section{Process}

We conducted semi-structured interviews lasting 30-60 minutes either in person or via telephone with knowledgeable individuals within each stakeholder category. Each stakeholder was asked openended questions about usability and safety practices and challenges during implementation. Prior to the interviews the research team discussed and agreed upon an initial set of questions (sample questions are in $>$ Table 2) and the purpose of each stakeholder group interview to maintain consistency across the interviews. Participants in each stakeholder category were asked questions relevant to their specific expertise; consequently, participants in each category were asked different questions. During each interview different follow-up probing questions were asked to pursue relevant topics and to obtain more specific information.

\section{Data analysis}

Responses were documented during each interview, and notes were transcribed and combined into a single data file immediately afterwards. Once all of the interviews were complete, six members of 
the research team conducted a qualitative analysis. The data were sorted by topic and emerging themes were identified using a grounded theory approach, with a focus on the practices and challenges described during each interview. ${ }^{21}$ Any discrepancies around the content and themes were discussed by the six-member team and if resolution could not be reached it was brought to the team of all authors for resolution.

\section{Analysis to identify alignment between the literature and stakeholders}

Six members of the research team examined the themes and content from the literature review and stakeholder interviews. The themes and content were synthesized to identify gaps between the literature and stakeholder interviews using a grounded theory approach. A gap was defined, a-priori, as a difference in knowledge content and focus between the literature and stakeholders. These gaps were often challenges expressed by stakeholders that did not have best practices or guidelines in the literature. If the literature mentioned the theme that was identified from the stakeholders, but did not provide concrete practices or guidance on how to overcome the challenge this was noted as a gap in the literature. Any discrepancies were discussed by all authors to reach resolution.

\section{Results}

\section{Study Selection and Characteristics}

The initial search resulted in 3676 articles. The flow diagram in $>$ Figure 1 details the selection process, which resulted in 55 articles. Of the 55 included articles, 29 were empirical articles presenting findings based on qualitative analysis of interviews and surveys of individuals involved in an implementation and 11 articles described case studies or lessons learned. Nine articles presented expert perspective or guidelines, and 6 articles were literature reviews focused on aspects of the overall process of implementation. Twenty-three of the articles were general articles that highlighted practices and challenges.

\section{Synthesis of Results and Emerging Themes}

The qualitative analysis of the literature search data and the interview data resulted in emerging themes in practices and challenges. The themes were cost and resources, risk assessment, governance and consensus building, customization, clinical workflow and usability testing, and training. - Table 3 summarizes the literature review and stakeholder data by emerging theme with identified gaps. The general articles are briefly summarized, with greater focus on articles addressing specific aspects of implementation.

\section{Cost and Resources}

\section{Findings in the Published Literature}

One general article highlighted cost as a major issue, particularly for small healthcare institutions.[24] Two articles specifically addressed costs during implementation. One categorized the major costs during implementation; the usability and safety related categories included infrastructure such as hardware (monitors, PCs, etc.), software including integration engines, a category of "other costs and materials" including training materials and software testing, and personnel including trainers and usability experts [25]. This article states that training and implementation costs are the most likely categories for healthcare institutions to focus on when attempting to reduce costs. These areas are recognized as being important to successful EHR implementation and use. Costs associated with testing of the software system and additional staff to back-fill and allow for appropriate training were highlighted as areas that are typically underestimated by healthcare institutions. The other article described a cost savings strategy that was focused on collaboration and sharing of information across healthcare institutions. Critical access hospitals collaborated to reduce the resource burden of implementing a new EHR, including sharing information on workflow processes $[26]$.

C) Schattauer 2016 R Ratwani et al.: Identify usability and safety challenges and practices during EHR implementation 


\section{Key Stakeholder Perceptions}

Small and large healthcare institutions, as well as researchers, discussed cost and resources as a major challenge. Health institutions - were concerned about the costs of making their systems more usable and safe. Small healthcare institutions commented that the products they were shown during demos were considerably different from those implemented, and that additional features to make the product more usable came with additional costs. Many small healthcare institutions also described the unexpected costs of training, including one who commented that the actual cost of a truly usable and safe system is unknown until implementation is complete. One researcher stated that health institutions are cost conscious during implementation, which poses challenges when usability and safety features may come at an additional expense. Association stakeholders also described the ambiguity over total cost of the implemented product. Health IT developers and consultants described how costs were dependent on the current infrastructure of the healthcare institution and that often times new hardware is required to improve usability and safety. Consultant stakeholders that focus on EHR optimization commented that despite their services being an added cost many large healthcare institutions are purchasing their services to focus on improving usability.

\section{Gap}

Few articles addressed the cost of implementation. There was alignment between the literature and stakeholders on general cost categories such as training and infrastructure. However, healthcare institutions desire a method for accurately estimating the total cost of implementation of usable and safe system. No articles addressed how to work with health IT developers and/or consultants to understand total costs of the implemented product.

\section{Risk Assessment}

\section{Findings in the Published Literature}

Five general articles stressed the importance of safety checks, having appropriate processes to communicate safety hazards, and conducting post-go-live audits [27-31]. Six articles specifically addressed risk assessment and included models for risk assessment and survey-based methods to identify areas for improvement within the EHR system. Four articles described models for risk assessment, three of which applied their models to CPOE. One approach used retrospective incident reports and prospective high-risk process identification to set priorities during implementation [32]. The second approach used a proactive risk assessment method using human factors and clinical experts and the third approach described a CPOE simulation tool to verify appropriate functionality $[33,34]$. The fourth approach is a proactive risk self-assessment tool, called the Safety Assurance Factors for EHR Resilience (SAFER) guides, which can be used during implementation to identify areas of vulnerability including usability and optimization [35]. The SAFER guides enable health institutions to perform their own assessments with relevant health IT stakeholders, including developers.

Two articles described survey-based methods to identify problem areas during implementation and go-live. One survey tool, based on the Systems Engineering Initiative for Patient Safety model (SEIPS), focused on evaluating EHR implementation, and can be used to assess usefulness and satisfaction [36]. The other survey described focused on user experience to identify areas for improvement including the concept domains: training and competency, usability, infrastructure, usefulness, and end-user support [37].

\section{Key Stakeholder Perceptions}

Research stakeholders described the need for increased risk assessment and the challenges with identifying health IT related safety events. One association stakeholder remarked on the benefits of the SAFER guides, but mentioned that they are not widely known by the health institution community. Several health institutions described the need for practical tools to identify usability-related safety issues during clinician use of the EHR, such as processes for reporting of usability and safety related events. These tools need to be integrated during implementation so that they are readily 
available during use, to streamline identification and remediation of issues. Consultants stated that few practical risk assessment tools exist. Proactive risk assessment was not a topic many health IT developer stakeholders discussed.

\section{Gap}

While the literature focused on the development of proactive risk assessment methods and tools, awareness and use of these tools by healthcare institutions and consultants was lacking. In addition, healthcare institution stakeholders focused on the need for methods to facilitate identifying, reporting, and addressing usability and safety hazards during product use.

\section{Governance and Consensus Building}

\section{Findings in the Published Literature}

Numerous general articles discussed the need to engage a diverse set of experts and end users, and the need for extensive planning with reasonable timelines [24, 27-31, 38-50]. Many of these articles highlighted the rushed timelines health institutions face; however, there were few concrete guidelines on how to address usability needs within compressed timelines.

Three articles specifically addressed governance structures and processes for building consensus during implementation. The implementation of the EHR requires making decisions on workflow processes, screen layouts, clinical decision support (CDS) rules, and other functionality - decisions directly tied to the usability and safety of the EHR. One article compared the governance structures and content management processes at five different institutions to compare CDS implementations, and provided recommendations including prioritization of work and providing a mechanism to gather user feedback [51]. Recommendations from an article describing use of Delphi methods to translate clinical policies into CDS include making CDS actionable, information easily consumable by clinicians, and allowing for clinician customization [52].

\section{Key Stakeholder Perceptions}

Small and large healthcare institutions described the need to have all staff on board for any EHR decision. Large healthcare institutions described their governance processes, which included clinical work groups, clinical informatics committees, and use of multidisciplinary expert teams during implementation. One consultant said that large healthcare systems have governing bodies that work well, but that small healthcare institutions struggle with governance and generally one or two individuals within the healthcare institution makes decisions without adequate end-user input. Small healthcare institutions and consultant stakeholders generally did not explicitly discuss governance structure and processes, but did discuss customization, which involves governance of the customization process. Small healthcare institutions described challenges with having the knowledge and expertise to make informed decisions about the product. Some associations stated that they provide recommendations for CDS and other features of the product to support healthcare institutions. Health IT developers described the importance of a rigorous governance process for successful implementation.

\section{Gap}

The literature focused on the need for multidisciplinary teams of experts during implementation. Stakeholders revealed that multidisciplinary teams are more commonly a best practice for large healthcare institutions that may have such expertise and resources available. Smaller healthcare institution stakeholders expressed that they lack the knowledgeable experts for effective governance. The literature does not provide concrete guidance and best practices for small institutions to overcome this barrier. 


\section{Customization}

\section{Findings in the Published Literature}

Five general articles described the importance of allowing some level of customization to meet clinician needs [29, 38, 43, 44, 47]. Three articles focused specifically on customization. One described an EHR platform that allows individual users to configure the system according to their needs, with benefits over traditional EHR systems based on established theoretical concepts and research-informed usability guidelines [53]. The second was specific to alert fatigue with CDS and described an effective customization of alerts by engaging experts, reviewing the literature, and reviewing CDS with a different set of experts once established [54]. The final article described recommendations from a panel of experts regarding specific customizations to improve safety and utility in the pediatric setting [55].

\section{Key Stakeholder Perceptions}

Several stakeholders discussed customization, and both health institutions and developers described how customization decisions during implementation have a significant impact on usability and safety. One small healthcare institution expressed that the long-term costs of customization, only realized when upgrades or other system modifications are needed, are not fully understood by health institutions and are not clearly explained by developers. Similarly, some health institutions expressed the desire for developers to provide more guidance on customization given developers' extensive experience with implementation. Health institutions and associations described a move toward configuration rather than customization. Several health institutions and associations expressed that they were moving away from extensive local customization and are seeing improved usability. One described usability and safety challenges for health institutions that work at multiple sites, all on the same EHR, but experience different levels of usability because of variations in customization of that EHR. One health institution commented on the lack of usability expertise and standard processes during customization, and one health institution suggested looking to specialty associations for guidance.

Health IT developer feedback on customization varied. Some developers described extensive customization when working with health institutions, although only a few developers included usability experts during this process. Others described their processes as prescriptive, allowing little to no customization. Consultants described how healthcare institution customization that is not informed by human factors principles can lead to serious safety challenges. Associations discussed how many of their member healthcare institutions do customize, but did not offer any additional details on customization.

\section{Gap}

The literature focused on using experts to guide customization. Although some stakeholders preferred less customization, health institutions were looking for guidance when customizing, often from developers, on what aspects of the EHR should be customized, and the long-term costs and consequences of customization.

\section{Clinical Workflow and Usability Testing}

\section{Findings in the Published Literature}

Several general articles stressed the importance of usability assessment, pilot testing on end-users, and workflow design, including the impact of poor interoperability on workflow $[24,27-31,38-40$, $43,46,49,56-58]$. Nine articles specifically addressed aspects of clinical workflow and usability testing. Using a sociotechnical evaluation approach, one article identified clinical workflow as a key theme that can result in failure during implementation [59]. Similarly, another article stressed the need for cross-functional implementation teams including experts in workflow and design to ensure these critical aspects are part of implementation [60].

There were different methods described for analyzing workflow and conducting usability evaluations. One article described the use of technology mediators, who understand end user's workflows 
and practices, to assist during implementation. The mediators establish credibility with the endusers and have knowledge of their technical abilities [61]. Another article focused on the study of communication patterns between physicians and nurses to better understand their needs and inform the implementation process to avoid negative impacts of technology on communication and workflow [62]. One article described a typology of temporary and routinized EHR workarounds [63].

Two articles described the use and importance of simulation during implementation and go-live to identify the impact of the EHR on workflow and determine whether clinicians can identify information critical to patient care via the $\operatorname{HER}[64,65]$ and one described the processes required to transform a simulation center into an EHR testing laboratory to examine usability [66]. Several articles described different methods for testing usability, including simulation, verbal protocol, and heuristic evaluations of the test system with the intended users to identify critical issues $[65,67]$.

\section{Key Stakeholder Perceptions}

Health institutions described several challenges and practices around workflow and testing. Workflow decisions are uninformed because health institutions do not know best practices on workflows. Health institutions indicated that changes to workflow within the EHR are burdensome, and some described difficulties in working with their developer to institute changes. Health institutions discussed how challenges with interoperability affect workflow and usability, for instance requiring manual data re-entry or reducing the availability of key data.

Small healthcare institutions had some strategies for workflow design and usability testing. One described looking to other similar practices to understand how those health institutions' workflows are affected by use of the EHR and then adopting insights in their own practice, and one described analyzing their own workflows and conducting pilot testing with some health institutions before making any implementation decisions that would be rolled out to all staff. Several health institutions described going to EHR user conferences to meet and learn from other health institutions. One small healthcare institution described going through each click and each screen to adjust workflows and remove extraneous information. Several also described hiring consultants to perform workflow analyses and advise on optimization, but some noted that workflow consultants that understand a specific EHR product well were hard to find.

One consultant indicated that many health institutions are unaware of their EHR's complete functionality and may be using suboptimal workflows as a result. One researcher discussed how rushed implementation timelines present a major challenge for health institutions to analyze workflows and integrate them into the EHR. EHR developers described their usability testing processes during design and development, but stated that usability testing is not a focus during implementation.

\section{Gap}

The literature and stakeholders recognize the critical importance of workflow design and usability testing; however, many health institutions felt uncomfortable making workflow decisions without detailed knowledge of workflow patterns. Large healthcare institutions in particular have complex workflow processes, do not have the workflow knowledge, and look to EHR developers to support the process of understanding workflow needs and implementing products to meet these needs. Similarly, many health institution stakeholders did not have the knowledge of how to perform usability tests during implementation.

\section{Training}

\section{Findings in the Published Literature}

Several general articles highlighted training and support for clinicians as a critical component of implementation $[24,25,27-31,39-46,50,56,57,68-71]$. These articles suggested tiered training approaches, varied training depending on clinician expertise, peer-training with clinical scenarios, and having 24-hour support available for health institutions [25, 29, 39, 43, 45]. 
Six articles focused specifically on training and described various aspects of training including training development and timing, and suggested best practices. One article focused on the development of training materials and highlighted the need for human factors techniques, such as task analysis, to identify the critical EHR tasks that should be the focus of training content [72]. One article described informatics and computer skill gaps as a major barrier to EHRs and suggested that EHR training should begin during formal medical education, prior to being a licensed clinician, to combat these barriers [73]. One article described the cost of training programs and detailed the high cost of education and identified barriers including hiring fill-in staff while others attend training [25].

Two articles focused on different training strategies, including simulation, resulting in positive effects such as increased self-confidence and preparedness [74]. One identified specific behaviors that increased super users' impact on peers' learning, such as being more engaged and proactive, providing comprehensive explanations for actions, and sharing information [75].

Two articles identified challenges and best practices. One focused primarily on the barriers and usability challenges in EHR education and training, including the burdensome length of training time, need for tailored training for specialist positions, lack of a systematic way to gauge learning, and inadequate resources such as experienced staff and time for retraining [76]. The other identified seven overall best practices in EHR implementation training, including: assess users' skills and needs, select appropriate trainers, and match training to users' needs, retrain, and optimize [77].

\section{Key Stakeholder Perceptions}

Several small and large healthcare institutions discussed training and its effects on end users' experiences and perceptions of EHR usability. One small healthcare institution described the challenge of having the right training for the right individual user, given differences in computer literacy and comfort. Health institutions discussed challenges posed by long delays between training and go-live, and one described how delivering large amounts of training in a short time resulted in poor learning. Several researchers discussed the need for continued training after "go live". Several health institutions had established their own training practices, including a continuous model with experts on site once a month, refresher training, and one on one peer consults. One consultant said that shadowing providers to see them use the system was very effective but costly and hard to scale. For nearly all health institutions, the high cost of training was a major issue. Several health IT developers expressed the importance of training on effective use of the product. Consultants described how many clinicians are unaware of core functionality within the EHR, which leads to inefficient workarounds, and how improved training could address this issue.

\section{Gap}

Several articles describe training methods, most of which are cost intensive and require specialized expertise and simulation. Stakeholders recognize the importance of training, but the cost of training was a significant challenge. While the literature provides information on the general costs of different training approaches, healthcare institution stakeholders are looking for clear guidance on effective low-cost training solutions and knowledge on how to train their staff on the implemented system in a time-frame that maximizes learning. Practical guidance on training strategies within the tight timelines of EHR implementation and cost-effective training solutions is currently unmet in the literature.

\section{Discussion}

EHR usability can dramatically affect clinicians' satisfaction with the system and the system's ability to enable consistently safe and high-quality care. Decisions made during EHR implementation can have a profound impact on the usability and safety of the system; improving implementation processes to optimize EHR usability and safety can help EHRs reach their full potential. We identified several gaps between the literature and the perspectives and practices of stakeholders working to improve the implementation process, making clear that additional research and resource development are needed to fill these gaps and to provide stakeholders with the knowledge and insight they need 
to successfully implement EHRs. Specifically, concrete guidance and best practices are needed to support small healthcare institutions in finding the appropriate expertise during implementation, identifying aspects of the EHR that should be customized, identifying cost effective methods for training, and identifying and ameliorating usability-related issues in implemented systems. Improvements in usability should also improve the ability for users to learn how to use EHRs which could reduce the burden of training.

In addition to research, other initiatives currently underway can serve to fill existing gaps. Transparency around costs associated with improving usability and safety of products during implementation was a major concern for health institution stakeholders and was not addressed in the literature. The ONC Certified Technology Comparison Task Force and the Senate Health, Education, Labor and Pensions committee have discussed this particular gap and have both recognized and promoted the need for improved EHR usability comparison tools. Poor system interoperability also has a major impact on usability and poses several challenges to efficient workflow which can pose risks to patient safety. Improved interoperability initiatives, which are a major priority for the ONC and Health and Human Services (HHS), will have a dramatic impact on usability and safety by creating more seamless workflow experiences for clinicians and reducing the need for customization [66].

Three underlying themes bridged many of the identified gaps. First, when tools and processes are available in the literature, they are not always being effectively disseminated and/or translated for frontline implementer and end users. Second, costs during implementation remain a significant challenge, particularly for small healthcare institutions, and much of the literature does not consider it when offering best practices. There is the potential for significant return-on-investment for improving EHR usability during implementation to prevent downstream inefficiencies, clinician frustration, and safety hazards; however, these benefits must be more clearly demonstrated to healthcare professionals adopting the technology and developers should support improvements in usability. Finally, improved partnerships between health institutions, developers, and other stakeholders are necessary to improve EHR usability and safety. Addressing these challenges will require coordination and engagement form multiple stakeholders making the ONC proposed health IT safety collaborative a particularly appropriate venue [78].

\section{Study Limitations}

This study aimed to identify gaps in the published literature in areas important to key stakeholders in EHR implementation, and used established methods in literature review and qualitative analysis. There are limitations to this approach. The focus of our literature search and stakeholder interviews was on usability and we did not explicitly differentiate between usability and usefulness. The stakeholders may have conflated these two concepts in their responses. Stakeholder responses are the respondents' perception of usability and stakeholders have varying degrees of understanding and experience with usability assessments. As with any literature review, the choice of inclusion criteria has the potential to bias the results by unknowingly including less relevant data or excluding relevant data. This was minimized by selecting criteria based on established literature and by using three independent reviewers during the review process. The semi-structured interview portion of the study also has potential limitations. As with any purposive sampling strategy, we recruited participants most likely to be knowledgeable on targeted topics. Despite our best efforts, it is possible that some perspectives were not represented. However, we used well-established, rigorous qualitative research methods to minimize this risk. In addition, each stakeholder group was asked different questions about usability and safety during implementation given that each stakeholder group has their own unique expertise.

\section{Conclusion}

Decisions made during implementation directly affect the usability and safety of the EHR. We identified several usability and safety gaps affecting implementation by examining misalignments be- 
tween the literature and key stakeholder perceptions. The major gaps were: transparency around cost and resources, risk assessment, governance and consensus building around EHR product options, customization, clinical workflow and usability testing, and training. Future research and resource dissemination should focus on these areas, and particularly on translation from the research realm to EHR implementation on the frontlines.

\section{Conflicts of Interest}

The authors have not conflicts of interest to report.

\section{Human Subjects Protections}

This research effort was determined to be exempt by the institutional review board. 


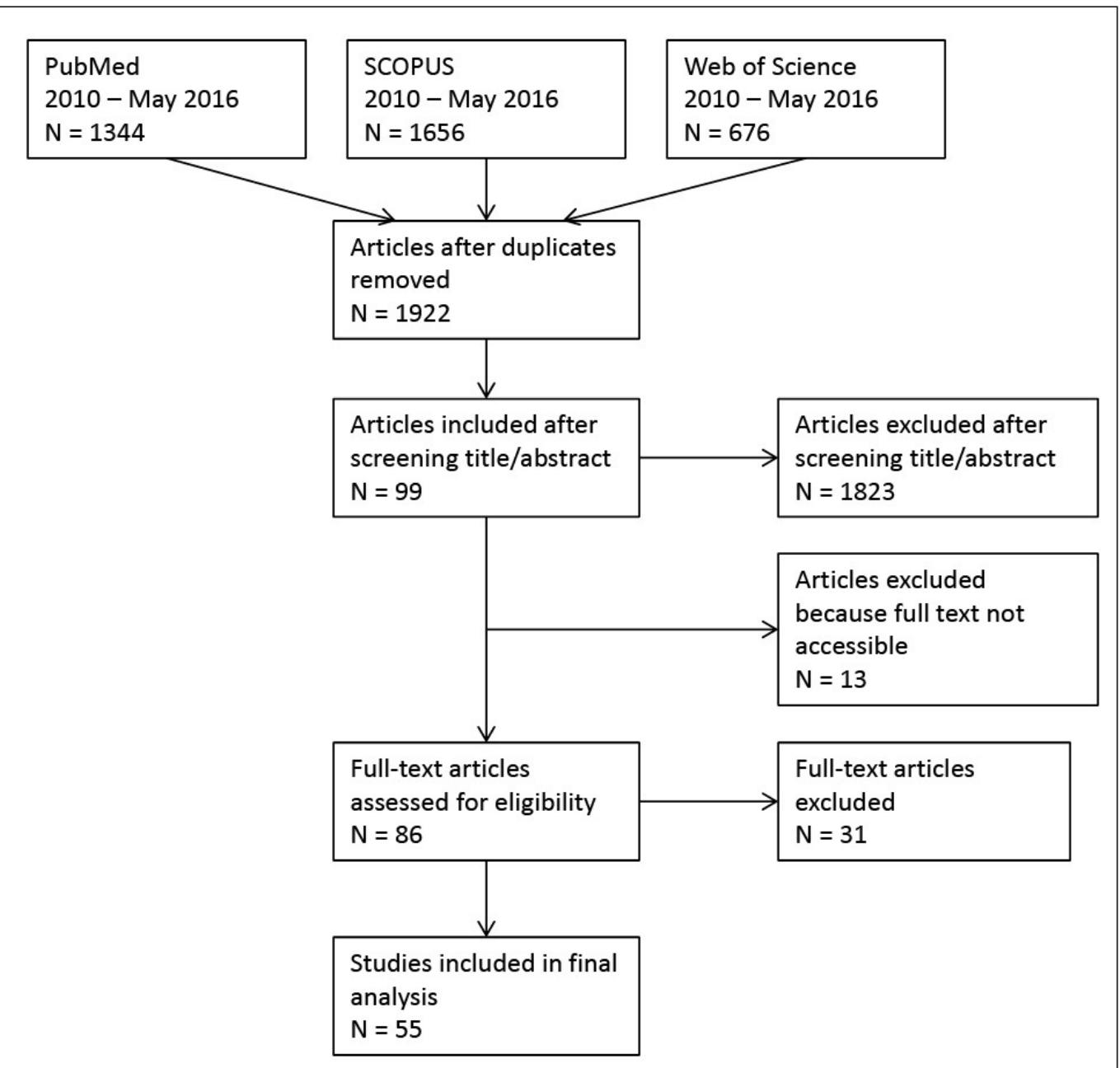

Fig. 1 Article selection process. 


\begin{tabular}{|c|c|c|c|c|}
\hline Concept 1 & & Concept 2 & & Concept 3 \\
\hline $\begin{array}{l}\text { electronic health record } \\
O R \\
\text { EHR } \\
O R \\
\text { electronic medical record } \\
O R \\
\text { EMR } \\
O R \\
\text { CPOE } \\
O R \\
\text { clinical decision support } \\
O R \\
C D S\end{array}$ & AND & $\begin{array}{l}\text { implementation* } \\
\text { OR } \\
\text { customization* } \\
\text { OR } \\
\text { training* } \\
\text { OR } \\
\text { configuration* }\end{array}$ & AND & $\begin{array}{l}\text { safety } \\
\text { OR } \\
\text { usability }\end{array}$ \\
\hline
\end{tabular}

Table 1 Search queries and restrictions.

Restrictions: published 2010 - May 16, 2016; peer-reviewed journal; affiliated author country: Australia, Canada, United Kingdom, United States of America; * indicates the word was identified as a stem term during search

Table 2 Stakeholder categories.

\begin{tabular}{|c|c|c|c|c|}
\hline $\begin{array}{l}\text { Category of } \\
\text { Stakeholder }\end{array}$ & $\begin{array}{l}\text { Description of } \\
\text { Stakeholder }\end{array}$ & $\begin{array}{l}\text { Participating } \\
\text { Individuals or } \\
\text { Organizations }\end{array}$ & $\begin{array}{l}\text { Stakeholder } \\
\text { Background }\end{array}$ & Sample Questions \\
\hline $\begin{array}{l}\text { Academia \& } \\
\text { Research }\end{array}$ & $\begin{array}{l}\text { Organizations } \\
\text { that aim to do } \\
\text { further research } \\
\text { or analysis of } \\
\text { health IT usabil- } \\
\text { ity and safety. }\end{array}$ & 8 & $\begin{array}{l}3 \text { focused on } \\
\text { nursing in- } \\
\text { formatics } \\
2 \text { focused on } \\
\text { safety science } \\
1 \text { focused on } \\
\text { physician in- } \\
\text { formatics } \\
2 \text { focused on } \\
\text { health IT }\end{array}$ & $\begin{array}{l}\text { 1. Do you know of any best prac- } \\
\text { tices around implementation } \\
\text { strategies both internal and exter- } \\
\text { nal to healthcare? } \\
\text { 2. Do you know of case studies or } \\
\text { research/planned research around } \\
\text { how EHR purchasers implement } \\
\text { new products and what recom- } \\
\text { mendations vendors make? }\end{array}$ \\
\hline $\begin{array}{l}\text { Associations \& } \\
\text { Societies }\end{array}$ & $\begin{array}{l}\text { Organizations } \\
\text { that operate to } \\
\text { represent the } \\
\text { needs or further } \\
\text { the interests of } \\
\text { individuals with } \\
\text { a common pro- } \\
\text { fessional back- } \\
\text { ground. }\end{array}$ & 8 & $\begin{array}{l}6 \text { Healthcare fo- } \\
\text { cused associ- } \\
\text { ations } \\
2 \text { Healthcare } \\
\text { technology fo- } \\
\text { cused associ- } \\
\text { ations }\end{array}$ & $\begin{array}{l}\text { 1. Do you have or know of any cur- } \\
\text { rent efforts around usability that } \\
\text { your organization does on behalf } \\
\text { of members? } \\
\text { 2. Does your organization catalog } \\
\text { UX efforts across quality and } \\
\text { safety initiatives? }\end{array}$ \\
\hline Consultants & $\begin{array}{l}\text { Organizations } \\
\text { that provide ex- } \\
\text { pert advice and } \\
\text { services on EHR } \\
\text { technology, such } \\
\text { as implemen- } \\
\text { tation advise- } \\
\text { ment and usabil- } \\
\text { ity optimization. }\end{array}$ & 8 & $\begin{array}{l}1 \text { focused on } \\
\text { healthcare in- } \\
\text { formatics } \\
3 \text { focused on im- } \\
\text { plementation } \\
4 \text { focused on } \\
\text { human factors/ } \\
\text { usability }\end{array}$ & $\begin{array}{l}\text { 1. How do you assist health institu- } \\
\text { tions adapt their implementation } \\
\text { process to improve usability and } \\
\text { patient safety? } \\
\text { 2. What workarounds or strategies } \\
\text { have frontline staff implemented } \\
\text { to improve their EHRs? }\end{array}$ \\
\hline
\end{tabular}


Table 2 Continued

\begin{tabular}{|c|c|c|c|c|}
\hline $\begin{array}{l}\text { Category of } \\
\text { Stakeholder }\end{array}$ & $\begin{array}{l}\text { Description of } \\
\text { Stakeholder }\end{array}$ & $\begin{array}{l}\text { Participating } \\
\text { Individuals or } \\
\text { Organizations }\end{array}$ & $\begin{array}{l}\text { Stakeholder } \\
\text { Background }\end{array}$ & Sample Questions \\
\hline $\begin{array}{l}\text { Health IT } \\
\text { Developers }\end{array}$ & $\begin{array}{l}\text { Private com- } \\
\text { panies that de- } \\
\text { sign, develop, } \\
\text { and sell EHRs. }\end{array}$ & 9 & $\begin{array}{l}9 \text { Health IT De- } \\
\text { velopers }\end{array}$ & $\begin{array}{l}\text { 1. Do you know of any work to track } \\
\text { or report health IT usability issues } \\
\text { across purchasers or to vendors? } \\
\text { 2. What does your organization do } \\
\text { to improve the implementation } \\
\text { process? }\end{array}$ \\
\hline $\begin{array}{l}\text { Health } \\
\text { Institutions }\end{array}$ & $\begin{array}{l}\text { Professionals } \\
\text { and organiz- } \\
\text { ations that use } \\
\text { health IT as part } \\
\text { of their health } \\
\text { care delivery pro- } \\
\text { cess. }\end{array}$ & 9 & $\begin{array}{l}2 \text { Nurses with IT } \\
\text { role } \\
3 \text { Physicians with } \\
\text { IT role } \\
4 \text { Physicians }\end{array}$ & $\begin{array}{l}\text { 1. Do EHR vendors provide you with } \\
\text { information on the best ways to } \\
\text { implement a new product? } \\
\text { 2. Do you have other groups or or- } \\
\text { ganizations that you contact for } \\
\text { implementation suggestions? } \\
\text { 3. What resources would be helpful } \\
\text { to your organization in making } \\
\text { implementation decisions? }\end{array}$ \\
\hline
\end{tabular}

Table 3 Summary of literature, stakeholder data, and major gaps by emerging theme.

\begin{tabular}{|c|c|c|c|}
\hline Themes & Literature & Stakeholders & Gaps \\
\hline $\begin{array}{l}\text { Cost and } \\
\text { Resources }\end{array}$ & $\begin{array}{l}\text { - Framework for major } \\
\text { costs [26] } \\
\text { Cost saving strategy } \\
\text { through collaboration } \\
\text { [25] }\end{array}$ & $\begin{array}{l}\text { - Unclear picture of total cost } \\
\text { - Extra costs to improve usability and } \\
\text { safety }\end{array}$ & $\begin{array}{l}\text { Transparency around the } \\
\text { total costs of a usable } \\
\text { and safe EHR }\end{array}$ \\
\hline Risk Assessment & $\begin{array}{l}\text { Models for risk assess- } \\
\text { ment [32-35] } \\
\text { Tools to evaluate imple- } \\
\text { mentation[36, 37] }\end{array}$ & $\begin{array}{l}\text { - Little awareness of risk assessment } \\
\text { tools or models } \\
\text { - Desire for seamless usability and } \\
\text { safety reporting }\end{array}$ & $\begin{array}{l}\text { Literature focused on } \\
\text { proactive risk assessment } \\
\text { and stakeholders desire } \\
\text { practical risk assessment } \\
\text { tools and method for } \\
\text { seamless reporting of ha- } \\
\text { zards }\end{array}$ \\
\hline $\begin{array}{l}\text { Governance and } \\
\text { Consensus } \\
\text { Building }\end{array}$ & $\begin{array}{l}\text { "Engage end-users" } \\
\text { without suggestions of } \\
\text { how to do so-Gather } \\
\text { user feedback [51] } \\
\text { - Actionable CDS recom- } \\
\text { mendations [52] } \\
\text { - Easily digestible infor- } \\
\text { mation from developers } \\
\text { [52] } \\
\text { Clinician customization } \\
\text { [52] }\end{array}$ & $\begin{array}{l}\text { All staff involved in process } \\
\text { processes-Small healthcare institu- } \\
\text { tions challenged to find needed ex- } \\
\text { pertise }\end{array}$ & $\begin{array}{l}\text { Guidance and best prac- } \\
\text { tices need to be devel- } \\
\text { oped for small healthcare } \\
\text { institutions who may not } \\
\text { have multidisciplinary ex- } \\
\text { perts }\end{array}$ \\
\hline
\end{tabular}


Table 3 Continued

\begin{tabular}{|c|c|c|c|}
\hline Themes & Literature & Stakeholders & Gaps \\
\hline Customization & $\begin{array}{l}\text { - Individual configuration } \\
\text { can be effective [53] } \\
\text { - Effective customization } \\
\text { can be developed by } \\
\text { using experts, literature } \\
\text { [54] } \\
\text { - Customization recom- } \\
\text { mendations via panel } \\
\text { of experts [55] }\end{array}$ & $\begin{array}{l}\text { - Long term costs are not fully under- } \\
\text { stood } \\
\text { - Need more guidance from experi- } \\
\text { enced developers or usability ex- } \\
\text { perts } \\
\text { - Configuration over customization } \\
\text { - Less local customization = in- } \\
\text { creased usability }\end{array}$ & $\begin{array}{l}\text { Guidance on what should } \\
\text { be customized and costs } \\
\text { associated with customiz- } \\
\text { ation }\end{array}$ \\
\hline $\begin{array}{l}\text { Clinical } \\
\text { Workflow and } \\
\text { Usability Testing }\end{array}$ & $\begin{array}{l}\text { Need experts in work- } \\
\text { flow [60] } \\
\text { - Workflow is key failure } \\
\text { theme [59] } \\
\text { - Methods for analyzing } \\
\text { workflow [61-63] } \\
\text { - Simulation to test } \\
\text { workflow, usability } \\
\text { [64-66] } \\
\text { Methods for conducting } \\
\text { usability evaluations } \\
\text { [65, 67] }\end{array}$ & $\begin{array}{l}\text { Workflow experts with product } \\
\text { knowledge hard to find } \\
\text { - Best practices unknown } \\
\text { - Some small healthcare institutions } \\
\text { have developed strategies for work- } \\
\text { flow analysis } \\
\text { - Health institutions lacking full } \\
\text { knowledge of EHR functionality } \\
\text { - Rushed timelines }\end{array}$ & $\begin{array}{l}\text { Methods to better under- } \\
\text { stand current workflow } \\
\text { processes and whether } \\
\text { EHRs are meeting work- } \\
\text { flow needs; desire for } \\
\text { greater engagement from } \\
\text { HIT developers }\end{array}$ \\
\hline Training & $\begin{array}{l}\text { - Human factors tech- } \\
\text { niques to identify criti- } \\
\text { cal training content } \\
\text { [72] } \\
\text { EHR education and } \\
\text { training earlier in medi- } \\
\text { cal career [73] } \\
\text { - Successful use of super } \\
\text { users [75] } \\
\text { Challenges [76] and } \\
\text { best practices [75] }\end{array}$ & $\begin{array}{l}\text { - Challenge to find right training for } \\
\text { right clinician } \\
\text { - Short timeline for absorbing content } \\
\text { - Local established training practices }\end{array}$ & $\begin{array}{l}\text { Need for guidance and } \\
\text { best practices on low cost } \\
\text { and effective training sol- } \\
\text { utions that can be admin- } \\
\text { istered in short period of } \\
\text { time }\end{array}$ \\
\hline
\end{tabular}




\section{References}

1. Goldberg DG, Kuzel AJ, Feng LB, DeShazo JP, Love LE. EHRs in primary care practices: Benefits, challenges, and successful straegies. Am J Manag Care 2012; 18(2): e48-e54.

2. King J, Patel V, Jamoom EW, Furukawa MF. Clinical benefits of electronic health record use: National findings. Health Serv Res 2014; 49(1 PART 2): 392-404. PMID: 24359580

3. Bertman J, Skolnik N, Anderson J. EHRs Get a Failing Grade on Usability. Intern Med News [Internet]. 2010; Available from: http://psych.imng.com/fileadmin/content_pdf/imn/archive_pdf/vol43iss11/70587_main.pdf

4. Scheck A. Special Report: EHR Success All Comes Down to User-Friendliness. Emerg Med News [Internet]. 2011;33(5):26-27. Available from: http://content.wkhealth.com/linkback/openurl?sid=WKPTLP: landingpage\&amp;an=00132981-201105000-00002

5. Koppel R, Kreda DA. Healthcare IT usability and suitability for clinical needs: challenges of design, workflow, and contractual relations. Stud Health Technol Inform. University of Pennsylvania, Philadelphia, PA, USA. rkoppel@sas.upenn.edu; 2010;157:7-14. Available from: papers2://publication/uuid/ 93BD5076-2932-4681-BFCB-BF17C6192753

6. Middleton B, Bloomrosen M, Dente M a, Hashmat B, Koppel R, Overhage JM, Payne TH, Rosenbloom ST, Weaver C, Zhang J. Enhancing patient safety and quality of care by improving the usability of electronic health record systems: recommendations from AMIA. J Am Med Informatics Assoc 2013; Jan 25; 1-7. Available from: http://www.ncbi.nlm.nih.gov/pubmed/23355463 PMID: 23355463

7. IOM Committee on Patient Safety and Health Information Technology. Transcript. Barrister's Reporting Service; 2011.

8. International Standards Organization. ISO 9241: Ergonomics of Human System Interaction [Internet]. 2010. Available from: https://www.iso.org/obp/ui/\#iso:std:iso:9241:-210:ed-1:v1:en

9. Hettinger AZ, Ratwani R, Fairbanks RJ. New Insights on Safety and Health IT [Internet]. 2015. Available from: https://psnet.ahrq.gov/perspectives/perspective/181/new-insights-on-safety-and-health-it

10. Bisantz AM, Roth EM, Brickman B, Lin L, McKinney J. Integrating cognitive analyses in a large scale system design process. Int J Hum Comput Stud 2003; 58: 177-206.

11. Kushniruk AW, Patel VL. Cognitive and usability engineering methods for the evaluation of clinical information systems. J Biomed Inform 2004; 37(1): 56-76. Available from: http://linkinghub.elsevier.com/retrieve/pii/S1532046404000206 PMID: 15016386

12. Ratwani RM, Fairbanks RJ, Hettinger AZ, Benda N. Electronic Health Record Usability: Analysis of the User Centered Design Process of Eleven Electronic Health Record Vendors. J Am Med Informatics Assoc 2015; 22 (6): 1179-1182; DOI: 10.1093/jamia/ocv050

13. Viitanen J. Usability in Healthcare-An Analysis for the Development of Clinical Information Systems. 2010; Available from: http://www.soberit.hut.fi/kaipio/Viitanen_Research-plan_30112010.pdf

14.Zhang J, Walji M. TURF: Toward a unified framework of EHR usability. Journal Biomed Informatics 2011; 44(6): 1056-1067.

15. Department of Health and Human Services- Office of the National Coordinator for Health Information Technology. 2015 Edition Health Infomraiton Technology Certification Criteria, 2015 Edition Base Electronic Health Record Definition, and ONC health IT Certificaiton program modification. 2015.

16. Meeks DW, Takian A, Sittig DF, Singh H, Barber N. Exploring the sociotechnical intersection of patient safety and electronic health record implementation. J Am Med Inform Assoc 2013; 21(e1): e28-e34. Available from: http://eutils.ncbi.nlm.nih.gov/entrez/eutils/elink.fcgi?dbfrom=pubmed\&amp;id=24052536\&amp; retmode=ref\&amp;cmd=prlinks PMID: 24052536

17. Middleton B, Bloomrosen M, Dente MA, Hashmat B, Koppel R, Overhage JM, Payne TH, Rosenbloom ST, Weaver C, Zhang J. Enhancing patient safety and quality of care by improving the usability of electronic health record systems: recommendations from AMIA. J Am Med Inform Assoc 2013; 20(e1): e2-e8. Available from: http://jamia.bmj.com/cgi/doi/10.1136/amiajnl-2012-001458 PMID: 23355463

18. Slabodkin G. ONC Reports 4x Spike in Providers Switching EHR Vendors. Health Data Manag. 2015; Available from: http://www.healthdatamanagement.com/news/onc-reports-4x-spike-in-providers-switch ing-ehr-vendors

19. Fairbanks R, Crittenden CN, O'Gara KG, Wilson MA, Pennington EC, Chin NP, Shah MN. Emergency Medical Services Provider Perceptions of the Nature of Adverse Events and Near-misses in Out-of-hospital Care: An Ethnographic View. Acad Emerg Med 2008; 15(7): 633-640.

20. Otte-Trojel T, de Bont A, Rundall TG, van de Klundert J. What do we know about developing patient portals? a systematic literature review. J Am Med Informatics Assoc 2015; (April 2015): ocv114. Available from: http://jamia.oxfordjournals.org/lookup/doi/10.1093/jamia/ocv114 PMID: 26335985

21. Webiste PS. PRISMA Checklist. Website. http://www.prisma-statement. org/2.1.2\%20-\%20PRISMA\%202009\%20Checklist.pdf (accessed 25 April 2016). 
22. Corbin J. Grounded theory in practice. Sage; 1997.

23. Ratwani RM, Zachary Hettinger A, Kosydar A, Fairbanks RJ, Hodgkins ML. A framework for evaluating electronic health record vendor user-centered design and usability testing processes. J Am Med Inform Assoc 2016; 1-5. Available from: http://www.ncbi.nlm.nih.gov/pubmed/27375292 PMID: 27375292

24. Ajami S, Bagheri-Tadi T. Barriers for adopting electronic health records (EHRs) by physicians. Acta Inform Medica 2013; 21(2): 129-134. PMID: 24058254

25. Slight SP, Quinn C, Avery AJ, Bates DW, Sheikh A. A qualitative study identifying the cost categories associated with electronic health record implementation in the UK. J Am Med Inform Assoc 2014; 21(e2): e226-e231. Available from: http://jamia.oxfordjournals.org/content/21/e2/e226.abstract PMID: 24523391

26. Wakefield DS, Ward MM, Loes JL, O'Brien J. A network collaboration implementing technology to improve medication dispensing and administration in critical access hospitals. J Am Med Inform Assoc 2010; 17: 584-587. PMID: 20819868

27. Bobb AM, Boehne J, Ethridge L, Hardy JC, Jacobs RS, Michael A, Lynch TW, Leslie R, Mannino TJ, Przybyla JJ, Reichert BJ, Runnebaum RM, Smestad NR, Troiano DL, Tyndall LL, Wright L, Clark T, Farthing K, Finkelstein BW, Fritz WL, Galt KA, Goldspiel BR, Jordan M, Marino RB, Kevin C, Meisel S, Miller AS, Mitchell S, Patel KR, Perry AB, Poikonen J, Siska MH, Windle M. ASHP guidelines on pharmacy planning for implementation of computerized provider-order-entry systems in hospitals and health systems. Am J Heal Pharm 2011; 68(6): 537. PMID: 21378303

28. Lawler EK, Hedge A, Pavlovic-Veselinovic S. Cognitive ergonomics, soci-technical systems, and the impact of healthcare information technologies. Int J Ind Ergon 2011; 41.

29. Takian A, Sheikh A, Barber N. We are bitter, but we are better off: case study of the implementation of an electronic health record system into a mental health hospital in England. BMC Health Serv Res 2012; 12(1): 484. Available from: http://www.biomedcentral.com/1472-6963/12/484 PMID: 23272770

30. Cooley TW, May D, Alwan M, Sue C. Implementation of computerized prescriber order entry in four academic medical centers. Am J Heal Pharm 2012; 69(24): 2166-2173. PMID: 23230041

31. Ames E, Ciotti V, Mathis B. Meaningful abuse: The rush toward EHR implementation. Healthc Financ Manag 2011; 65(2): 70-73. PMID: 21428226

32. Van Der Veen W, De Gier HJJ, Van Der Schaaf T, Taxis K, Van Den Bemt PMLA. Risk analysis and user satisfaction after implementation of computerized physician order entry in Dutch hospitals. Int J Clin Pharm 2013; 35(2): 195-201. PMID: 23187963

33. Hundt AS, Adams JA, Schmid JA, Musser LM, Walker JM, Wetterneck TB, Douglas S V, Paris BL, Carayon P. Conducting an efficient proactive risk assessment prior to CPOE implementation in an intensive care unit. Int J Med Inf 2013; 82(1): 25-38. Available from: http://www.ncbi.nlm.nih.gov/pubmed/22608242 PMID: 22608242

34.Denham CR, Classen DC, Swenson SJ, Henderson MJ, Zeltner T, Bates DW. Safe use of electronic health records and health information technology systems: trust but verify. J Patient Saf 2013; 9(4): 177-189. Available from: http://graphics.tx.ovid.com/ovftpdfs/FPDDNCOBNFOANL00/fs047/ovft/live/gv024/01209203/ 01209203-201312000-00001.pdf PMID: 24257062

35. Sittig DF, Ash JS, Singh H. The SAFER Guides: Empowering Organizations of Electronic Health Records. Am J Manag Care 2014; 20(5): 418-423.

36. Hoonakker P, Cartmill RS, Carayon P, Walker JM. Development and psychometric qualities of the SEIPS survey to evaluate CPOE/EHR Implementaiton in ICSU. Int J Helathcare Inf Syst informatics 2011; 6(1): 51-69.

37.Xiao Y, Montgomery DC. Development of a Tool to Measure User Experience Following Electronic Health Record Implementation. J Nurs Adm 2014; 44(7): 423-428.

38. Cresswell KM, Lee L, Slee A, Coleman J, Bates DW, Sheikh A. Qualitative analysis of vendor discussions on the procurement of Computerised Physician Order Entry and Clinical Decision Support systems in hospitals: Table 1. BMJ Open 2015; 5(10): e008313. Available from: http://bmjopen.bmj.com/lookup/ doi/10.1136/bmjopen-2015-008313

39. Spetz J, Burgess JF, Phibbs CS. What determines successful implementation of inpatient information technology systems? Am J Manag Care 2012; 18(3): 157-162. PMID: 22435909

40. Silow-Carroll S, Edwards JN, Rodin D. Using Electronic Health Records to Improve Quality and Efficiency: The Experiences of Leading Hospitals. The Common 2012; (July): 1-40. Available from: http://www.com monwealthfund.org/ /media/Files/Publications/Issue Brief/2012/Jul/1608_SilowCarroll_using_EHRs_ improve_quality.pdf

41.Bernd DL, Fine PS. Electronic medical records: a path forward. Front Health Serv Manage 2011; 28(1): 3-13. PMID: 21961380

42. Nguyen L, Bellucci E, Nguyen LT. Electronic health records implementation邓: An evaluation of information system impact and contingency factors. Int J Med Inform 2014; 83(11): 779-796. Available from: http://dx.doi.org/10.1016/j.ijmedinf.2014.06.011

C) Schattauer 2016 R Ratwani et al.: Identify usability and safety challenges and practices during EHR implementation 
43. Propp DA. Successful introduction of an emergency department electronic health record. West J Emerg Med 2012; 13(4): 358-361. Available from: http://www.pubmedcentral.nih.gov/articlerender. fcgi?artid=3523896\&tool=pmcentrez\&rendertype=abstract PMID: 23251715

44. Muslin SI, Vardaman MJ, Cornell TP. Fostering Acceptance of Computerized Physician Order Entry. Health Care Manag (Frederick) 2014; 33(2): 165-171. Available from: http://search.ebscohost.com/

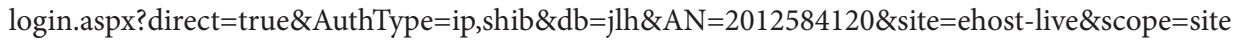

45.Simon SR, Keohane CA, Amato M, Coffey M, Cadet B, Zimlichman E, Bates DW. Lessons learned from implementation of computerized provider order entry in 5 community hospitals: a qualitative study. BMC Med Inform Decis Mak 2013; 13(1): 67. Available from: http://www.biomedcentral.com/1472-6947/13/67 PMID: 23800211

46. Haughom JL. Implementation of an electronic health record. BMJ (Clinical Res ed) [Internet]. 2011;343:d5887. Available from: http://eutils.ncbi.nlm.nih.gov/entrez/eutils/elink.fcgi?dbfrom= pubmed\&amp;id=21952445\&amp;retmode=ref\&amp;cmd=prlinks PMID: 21952445

47. Shaha JS, El-Othmani MM, Saleh JK, Bozic KJ, Wright J, Tokish JM, Shaha SH, Saleh KJ. The Growing Gap in Electronic Medical Record Satisfaction Between Clinicians and Information Technology Professionals. J Bone Jt Surg 2015; 1979-1984.

48.4Huryk LA. Factors influencing nurses' attitudes towards healthcare information technology. J Nurs Manag 2010; 18(5): 606-612. PMID: 20636510

49. Alonso AH, Gonzalez CGR, Saez MS. Information technology and automation in hospitals: Strategies and experience in a tertiary hospital in Spain. EJHP Pract 2011; 17(4): 26-31. Available from: http://www. eahp.eu/content/download/32026/201159/file/PRI26-31.pdf\%5Cnhttp://ovidsp.ovid.com/ovidweb. cgi? $\mathrm{T}=J S \& C S C=Y \& N E W S=N \& P A G E=$ fulltext $\& D=$ emed10\&AN=2011561950\%5Cnhttp $/ /$ sfxhosted. exlibrisgroup.com/cmc?sid=OVID:embase\&id=pmid:\&id=doi:\&issn=1781-9989\&isbn=\&vol $\quad$ PMID: 2011561950

50. Chen AR, Lehmann CU. Computerized Provider Order Entry in Pediatric Oncology: Design, Implementation, and Outcomes. J Oncol Pract 2011; 7(4): 213-218. Available from: http://www.pubmedcentral.nih. gov/articlerender.fcgi?artid=3140440\&tool=pmcentrez\&rendertype=abstract PMID: 22043182

51. Wright A, Sittig DF, Ash JS, Bates DW, Feblowitz J, Fraser G, Maviglia SM, McMullen C, Nichol WP, Pang JE, Starmer J, Middleton B. Governance for clinical decision support: case studies and recommended practices from leading institutions. J Am Med Inform Assoc 2011; 18(2): 187-194. Available from: http://www. pubmedcentral.nih.gov/articlerender.fcgi?artid=3116253\&tool=pmcentrez\&rendertype=abstract PMID: 21252052

52. Melnick ER, Nielson JA, Finnell JT, Bullard MJ, Cantrill S V., Cochrane DG, Halamka JD, Handler JA, Holroyd BR, Kamens D, Kho A, McClay J, Shapiro JS, Teich J, Wears RL, Patel SJ, Ward MF, Richardson LD. Delphi consensus on the feasibility of translating the ACEP clinical policies into computerized clinical decision support. Ann Emerg Med 2010; 56(4): 317-320. Available from: http://dx.doi.org/10.1016/j.annemergmed.2010.03.006 PMID: 20363531

53. Senathirajah Y, Bakken S, Kaufman D. The clinician in the Driver's Seat: Part 1 - A drag/drop user-composable electronic health record platform. J Biomed Inform 2014; 52: 165-176. Available from: http://dx.doi.org/10.1016/j.jbi.2014.09.002 PMID: 25240253

54. Horn JR, Hansten PD, Osborn JD, Wareham P, Somani S. Customizing clinical decision support to prevent excessive drug-drug interaction alerts. Am J Heal Pharm 2011; 68: 662-664.

55.Patterson ES, Zhang J, Abbott P, Gibbons MC, Lowry SZ, Quinn MT, Ramaiah M, Brick D. Enhancing Electronic Health Record Usability in Pediatric Patient Care: A Scenario-Based Approach. Jt Comm J Qual Patient Saf 2013; 39(3).

56. Irizarry T, Barton AJ. A sociotechnical approach to successful electronic health record implementation. Clin Nurse Spec 2013; 27(6): 283-285. Available from: http://content.wkhealth.com/linkback/openurl?sid=WKPTLP:landingpage\&an=00002800-201311000-00003 PMID: 24107749

57. Ash JS, Sittig DF, McMullen CK, Wright A, Bunce A, Mohan V, Cohen DJ, Middleton B. Multiple perspectives on clinical decision support: a qualitative study of fifteen clinical and vendor organizations. BMC Med Inf Decis Mak 2015; 15(1): 35. Available from: http://www.ncbi.nlm.nih.gov/pubmed/ 25903564\%5Cnhttp://www.ncbi.nlm.nih.gov/pmc/articles/PMC4447027/pdf/12911_2015_Ar ticle_156.pdf PMID: 25903564

58. Joukes E, Cornet R, Bruijne MC De, Keizer NF De. Eliciting end-user expectations to guide the implementation process of a new electronic health record: A case study using concept mapping. Int J Med Inform 2016; 87: 111-117. Available from: http://dx.doi.org/10.1016/j.ijmedinf.2015.12.014 PMID: 26806718

59. Peute LW, Aarts J, Bakker PJM, Jaspers MWM. Anatomy of a failure: A sociotechnical evaluation of a laboratory physician order entry system implementation. Int J Med Inform 2010; 79(4): 58-70. PMID: 19640778 
60. Chaffee BW, Zimmerman CR. Developing and implementing clinical decision support for use in a computerized prescriber-order-entry system. Am J Heal Pharm 2010; 67(5): 391-400. PMID: 20172991

61. Novak LL, Anders S, Gadd CS, Lorenzi NM. Mediation of adoption and use: a key strategy for mitigating unintended consequences of health IT implementation. J Am Med Inform Assoc 2012; 19(6): 1043-1049. Available from: http://www.scopus.com/inward/record.url?eid=2-s2.0-84867678039\&partnerID=tZOtx3y1 PMID: 22634157

62. Pelayo S, Anceaux F, Rogalski J, Elkin P, Beuscart-Zephir MC. A comparison of the impact of CPOE implementation and organizational determinants on doctor-nurse communications and cooperation. Int $\mathrm{J}$ Med Inform 2013; 82(12): 321-330. PMID: 22999779

63. Friedman A, Crosson JC, Howard J, Clark EC, Pellerano M, Karsh B-T, Crabtree B, Jaen CR, Cohen DJ. A typology of electronic health record workarounds in small-to-medium size primary care practices. J Am Med Inform Assoc 2014; 21(e1): e78-e83. Available from: http://jamia.bmj.com/cgi/doi/10.1136/ amiajnl-2013-001686

64. March CA, Steiger D, Scholl G, Mohan V, Hersh WR, Gold JA. Use of simulation to assess electronic health record safety in the intensive care unit: a pilot study. BMJ Open 2013; 3(4): e002549-e002549. Available from: http://www.pubmedcentral.nih.gov/articlerender.fcgi?artid=3641430\&tool=pmcentrez\&rendertype= abstract\%5Cnhttp://bmjopen.bmj.com/cgi/doi/10.1136/bmjopen-2013-002549 PMID: 23578685

65.Li AC, Kannry JL, Kushniruk A, Chrimes D, McGinn TG, Edonyabo D, Mann DM. Integrating usability testing and think-aloud protocol analysis with "near-live" clinical simulations in evaluating clinical decision support. Int J Med Inform 2012; 81(11): 761-772. Available from: http://dx.doi.org/10.1016/j.ijmedinf.2012.02.009 PMID: 22456088

66. Landman AB, Redden L, Neri P, Poole S, Horsky J, Raja AS, Pozner CN, Schiff G, Poon EG. Using a medical simulation center as an electronic health record usability laboratory. J Am Med Informatics Assoc 2014; 21(3): 558-563. Available from: http://jamia.oxfordjournals.org/lookup/doi/ 10.1136/amiajnl-2013-002233 PMID: 24249778

67. Corrao NJ, Robinson AG, Swiernik MA, Naeim A. Importance of testing for usability when selecting and implementing an electronic health or medical record system. J Oncol Pract 2010; 6(3): 120-124. Available from: http://jop.ascopubs.org/content/6/3/120.full PMID: 20808553

68. Chao CA, Goldbort J. Lessons Learned from Implementation of a Perinatal Documentation System. JOGNN - J Obstet Gynecol Neonatal Nurs 2012; 41(5): 599-608. PMID: 22690726

69. Green LA, Potworowski G, Day A, May-Gentile R, Vibbert D, Maki B, Kiesel L. Sustaining "meaningful use" of health information technology in low-resource practices. Ann Fam Med 2015; 13(1): 17-22.

70. Holden RJ. What stands in the way of technology-mediated patient safety improvements?: a study of facilitators and barriers to physicians' use of electronic health records. J Patient Saf 2011; 7(4): 193-203. Available from: http://www.pubmedcentral.nih.gov/articlerender.fcgi?artid=3220192\&tool=pmcentrez\&ren dertype=abstract PMID: 22064624

71.Dennehy P, White MP, Hamilton A, Pohl JM, Tanner C, Onifade TJ, Zheng K. A partnership model for implementing electronic health records in resource-limited primary care settings: experiences from two nurse-managed health centers. J Am Med Informatics Assoc 2011; 18(6): 820-826. Available from: http://jamia.oxfordjournals.org/content/18/6/820 PMID: 21828225

72. Patel AA, Ozok AA. Exploring training issues in healthcare: Towards identifying barriers to increase electronic medical records adoption by healthcare professionals. Lect Notes Comput Sci (including Subser Lect Notes Artif Intell Lect Notes Bioinformatics) 2011; 7058 LNCS: 657-671.

73. Miller L, Stimely M, Matheny P, Pope M, McAtee R, Miller K. Novice Nurse Preparedness to Effectively Use Electronic Health Records in Acute Care Settings: Critical Informatics Knowledge and Skill Gaps. Online J Nurs Informatics 2014; 18(2) (January).

74. Bramble JD, Galt KA, Siracuse M V, Abbott AA, Drincic A, Paschal KA, Fuji KT. The relationship between physician practice characteristics and physician adoption of electronic health records. Health Care Manage Rev 2010; 35(1): 55-64. PMID: 20010013

75. Yuan CT, Bradley EH, Nembhard IM. A mixed methods study of how clinician "super users" influence others during the implementation of electronic health records. BMC Med Inform Decis Mak 2015; 15(1): 26. Available from: http://www.biomedcentral.com/1472-6947/15/26 PMID: 25889076

76. Kim MS, Clarke MA, Belden JL, Hinton E. Usability Challenges and Barriers in EHR Training of Primary Care Resident Physicians 2014; 385-391.

77. McAlearney AS, Robbins J, Kowalczyk N, Chisolm DJ, Song PH. The role of cognitive and learning theories in supporting successful EHR system implementation training: a qualitative study. Med Care Res Rev 2012; 69(3): 294-315. Available from: http://www.ncbi.nlm.nih.gov/pubmed/22451617 PMID: 22451617

78.RTI International. Health IT Safety Center Roadmap. Available from: http://www.healthitsafety.org/ uploads/4/3/6/4/43647387/roadmap.pdf 